Kaygı, 20(I)/2021: 150-170. Araştırma Makalesi | Research Article

Makale Geliş | Received: 01.12.2020

Makale Kabul | Accepted: 19.02.2021

Yayın Tarihi | Publication Date: 15.03.2021

DOI: 10.20981/kaygi.889037

A. Özgür GÜRSOY

Dr. Öğr. Üyesi $\mid$ Assist. Prof. Dr. İzmir Ekonomi Üniversitesi, İletişim Fakültesi, Yeni Medya ve İletişim Bölümü, İzmir, TR İzmir Economy University, Faculty of Communication, Dep. of New Media and Communication, İzmir, TR

ORCID: 0000-0003-3332-9921

ozguraligursoy@gmail.com

\title{
Hakikatin Ötesi, Berisi, Kendisi: "Hakikat-ötesi”" Kavramına Dair Eleştirel Bir Çözümleme
}

$\ddot{\mathrm{O} z}$

"Hakikat-ötesi”, güncel toplumsal gerçekliğimizin ne olduğuna ve bugün karşılaştığımız birçok sorunun tasvirine dair tartışmalarda sıklıkla başvurulan bir kavrama dönüştü. Fakat yaygın tartışmalarda hakikatin ne olduğu sorusuna dair garip bir sessizlik söz konusudur. Bu durum bir yere kadar anlaşılabilir, çünkü bu soruyu mesele eden felsefe tarihinde genel uzlaşıya varılmış bir tanım yoktur. Fakat söz konusu sessizliğin bir riski, hakikati verili ve sadece bulunan bir şeymiş gibi varsayarak, bizleri savunması güç epistemoloji kuramlarına sığınmak zorunda bırakmak ve hakikat-ötesi dediğimiz durumun sebebini bir grup insanın cahilliğinde, aptallığında veya kötü niyetinde konumlandırmaktır. Bu çalışmanın amacı, hakikat-ötesi kavramının felsefi bir eleştirisini denemektir. Gerekçe arayışını neyin tatmin edebileceğine dair temel bir sorunu içeren bir yapının hatırlanması, kavramın kullanımlarının faydasına ve faydasızlığına ışık tutacaktır. Çalışmanın vardığı sonuç, hakikat-ötesi kavramının normatif ve betimsel düzlemlerde kaçınılmaz bir çift-anlamlılığı içerdiğidir. Hakikatötesi diyerek kavramsallaştırılmaya çalışılan toplumsal durumun tehlikesi, her şeyin tartışılır hale geldiği kuralsız bir görecilik değil, herhangi anlamlı bir tartışmayı imkânsız hale getiren toplumsal bir bölünmüşlük ve çatışma halidir. Öyleyse kavramın felsefi bir eleştirisinin göstereceği ilginç sonuç, hakikat-ötesinde söz konusu edilmek istenen meselenin — en genel anlamıyla—siyasi oluşudur.

Anahtar Kelimeler: Hakikat-ötesi, Gerekçelendirme, Kamusal Tartışma.

\section{The Hither Side of Truth: A Critical Appraisal of the Concept of "Post-Truth"}

\begin{abstract}
One finds frequent appeals to the concept of post-truth in current debates that seek to describe and explain contemporary social reality and its problems. However, there is a strange silence in these debates regarding what truth is. This situation is understandable to the extent that the attempts to formulate a concept of truth have not arrived at a satisfactory definition with universal acceptance. But there remains a significant risk attached to this silence: The debates on post-truth go on as if truth is something that is merely given or found, and thereby force us into either undefended assumptions or faulty epistemological theories - the implication being that the situation that is supposed to be captured by post-truth is due to either the ignorance, stupidity or ill-will of a group of people. The goal of the present study is a philosophical critique of the concept of posttruth. It argues that recalling a certain structural problem associated with our attempts to justify claims to knowledge sheds light on the uses and abuses of the concept of post-truth.. The conclusion of the present study is that the concept of post-truth suffers from a fundamental ambiguity between its descriptive and normative meanings. The real danger of the social situation indicated by "post-truth" is not a relativism in which every claim becomes debatable, but rather a social division and conflict in which genuine debate becomes impossible.
\end{abstract}


Therefore, a philosophical critique of the concept shows, ironically, that what is in question in the concept of post-truth is a political problem.

Keywords: Post-truth, Justification, Public Debate.

\section{Giriş}

Hakikat-ötesi, güncel toplumsal gerçekliğimizin ne olduğuna ve bugün karşılaştığımız birçok sorunun tasvirine dair tartışmalarda sıklıkla başvurulan bir kavrama dönüştü. Haliyle, bu kavramın barındırdığı farklı katmanlar farklı disiplinlerin bakış açılarının ve yöntemlerinin kullanıldığı birçok yayında konu edildi. ${ }^{1}$ Kamuoyunun şekillenmesinde etkili olan öğelerin dönüşümünün başlangıç noktası yapıldığı bu çalışmalar, meselenin katmanlarının farklılığını teslim etmekle beraber, çözümlemenin aracı olarak daha çok toplum bilimlerin söylemlerini-özellikle psikoloji, sosyoloji ve iletişim bilimleri-kullanmaktadır. Böylece kavramın felsefi boyutu gereken ilgiyi görmemektedir. Oysa geleneksel olarak hakikatin ve gerçekliğin ne olduklarını en temel soruları arasında saymış olan felsefi söylem, hakikat-ötesi kavramının çözümlemesinde önemli araçlara sahiptir.

$\mathrm{Bu}$ çalışmada esasen yapmak istediğim, hakikat-ötesi kavramının bir eleştirisini denemektir. Burada "kavramın eleştirisi" ifadesinin temel işlevi şudur: (1) Kavramın olanaklılık koşullarının sorgulanması ve böylece (2) onun meşru kullanımının sınırlarının belirlenmesi. Böyle bir eleştiriye gerek vardır. Çünkü, bilimsel bilginin değersizleşmesi, iklim değişikliğinin inkârı, aşı karşıtlı̆̆ı, sosyal medyada dezenformasyon kampanyaları ve muhtelif komplo teorileri gibi birbirlerinden farklı birçok olguyu kapsadığı iddia edilen hakikatin ötesinde olma durumunun tam olarak ne demek olduğu iki önemli hususta belirsizdir: (1) Kavram tarihsel bir dönemi mi yoksa

\footnotetext{
1 Söz konusu çalışmaların arasında bazıları şunlardır: Keyes 2004; Frankfurt 2005; D’Ancona 2017; Kakutani 2018; Kalpokas 2018; Harsin 2015 ve 2018; McIntyre 2018; Fuller 2018; Cosentino 2020; Legg 2018. Meselenin duyguları ve kitlesel yalanı ilgilendiren iki farklı boyutunun incelendiği iki çalışma için bkz., sırasıyla, Yazıcı 2020 ve Başkır 2020.
} 
temel bir tavrı mı işaret etmektedir? (2) Kavramın işlevi betimsel mi yoksa normatif midir? Öyleyse kavramın neyi nasıl kavradığı söz konusu edilmelidir. Aksi durumda kavramın taşıdığı bir risk, günümüz medya ve akademi ortamının bir yönelimini tatmin etmek ve böylece teşhis etmek istediği durumun bir semptomu olarak kalmaktır-yani her zamandan bir dönem çıkarmak ve toplumsal olguları etiketleyerek şeyleştirmek.

Hakikat-ötesine dair yaygın tartışmaların dikkat çekici bir özelliği, hakikatin ne olduğuna dair çoğunda hâkim olan bir sessizliktir. Bu sessizlik herhangi bir yazarın dikkatsizliğinden veya kazara olan bir şey değildir elbette. Çünkü hangi inanç veya önermelerin doğru oldukları meselesinin ötesinde, doğru olan inanç veya önermeleri doğru yapanın ne olduğunu-yani hakikatin kendisini-söz konusu eden felsefi düşünce tarihinde, evrensel veya yaygın bir uzlaşıya varılmış bir tanım yoktur. Fakat hakikat-ötesine dair tartışmalarda bu durumun yeterince teslim edilmiyor oluşu, şu ironik sonucu yaratmaktadır: Tartışmalar, hakikatin kendisi sanki sadece bulunan, verili, bariz veya tartışmasız bir şeymiş gibi varsayarak; sorunun önemli bir boyutunu yalnızca bir grup insanın cehaletinde, korkaklığında veya kötü niyetinde (örtük şekilde) konumlandırmaktadır. Bu tür negatif cevapların yalnızca varsayarak üzerinden geçtiği durum, hem hakikati olanaklı kılan ama kendisi bilişsel olmayan bir art alan olabileceği hem de nasıl olup da o kadar insanın tüm bu (bizim için) yanlış olan söylemlere inanabildiğidir. Öyleyse yapılması gereken, hakikatin tartışmalı bir şey olduğunu teslim etmek, ama ancak belirli tür bir tartışmanın hakikatle ilgili olabildiğini görünür k1lmaktır.

Hakikat-ötesi kavramının eleştirel bir çözümlemesine katkıda bulunmak adına, bu çalışmada ileri süreceğim ve gerekçelendireceğim birbirleriyle karmaşık ilişkiler içeren üç temel iddia olacak. Birincisi kavramın yaygın tanımına dairdir: Kamuoyunun şekillenmesinde nesnel olgulardan ziyade kişisel kanı veya duyguların etkili olması olarak sunulan hakikat-ötesinde esasen tanınması gereken durum; sadece verili olanın etkinliğine indirgenen bir nesnellikle eşzamanlı olarak, öznelliğin zayıflaması veya yok olmasıdır. Yani hakikat-ötesi durumunda söz konusu olanın öznelliğin nesnelliğe baskınlığı değil, belirli bir nesnellik anlayışının anlamlı bir öznelliğe yer bırakmaması 
olduğu düşünülmelidir. İkinci iddia, hakikat-ötesi durumunun önemli bir niteliği ve hatta kaynağı olarak belirtilen, bilimsel bilginin değersizleş(tiril)mesine dairdir: Hakikat-ötesi durumunu anlaşı1ır kılmak için yapılması gereken, bilimsel bilgiyi saf nesnelliğin tarafında konumlandırmak değil, (belirli bir) öznelliğin nesnelliğin kurulumundaki etkinliğini teslim etmektir. Burada söz konusu olan kurulumun iki boyutu vardır: (1) Herhangi belirli bir araştırma alanında, nelerin olgu sayılacağını belirleyen kuramsal ve kavramsal bir sınırlamanın gerekliliği ve (2) bilimsel bilginin otoritesinin kendisinin, bilimsel bilginin yöntemleriyle sağlama alınamayacağı. Yani ikinci iddianın savı, bilimsel bilginin değersizleşebiliyor oluşunda, bilimsel bilginin ne olduğuna dair baskın bir yanlış anlamanın payı olduğudur. Bu çalışmanın ileri süreceği üçüncü ve son iddia şudur: Nasıl olup da onca insanın tüm bu ("hakikat-ötesi”) söylemlere inanır olduğunu sadece negatif cevaplarla açıklamanın vardığı yer, sonucunu varsayan fasit dairesel argümanlardır; öyleyse hakikat-ötesi durumunu anlaşılır kılmak için faydalı olacak bir öğe, ortak bir dili olanaklı veya olanaksız kılan koşulların sorgulanmasidir.

Birinci iddiayı gerekçelendirmek adına, bir inanç veya önermeyi doğru yapan niteliğin ne olduğuna dair hem gündelik yaşamın sezgilerinde hem de felsefi gelenekte önemli bir yeri olan ve hakikati, inancın veya önermenin gerçekliğe denkliği olarak belirleyen hakikat kuramını motive eden gerekçelendirme etkinliğine has bir yapının içerdiği sorunları inceleyeceğim. Bu sorunları başlangıç noktası yapmak, nesnellik dediğimiz şeyin belirli bir öznellikten bağımsız düşünülemeyeceği görüşünü anlamlandıracaktır. Bunun devamı olarak, ikinci iddiada söz konusu olan ve bilimsel bilgiyi olanaklı kılan ve bu nedenle kendisi bilimsel bilginin nesnesi olmayan bir art alanın gerekliliğini gerekçelendirmek adına; bilimsel bilginin varsaydığı muazzam kuramsal ve deneysel bir yapının nesnelliğin kurulumundaki etkinliğini inceleyeceğim. Bu art alanı (veya olanaklılık koşullarını) üçüncü iddiada söz konusu olan "ortak dil”" kavramı ile özetleyeceğim.

Bu tür bir eleştirinin hatları şunu göstermeyi amaçlamaktadır: Hakikatin değerini savunmak, bizleri hakikat tartışmasız bir şeymiş gibi varsayarak konuşmaya 
itmemelidir. Eğer öyle olsaydı, içinde olduğumuz ve hakikat-ötesi kavramının kavramaya çalıştığı durumda olmazdık. Benzer şekilde, bilimsel bilginin değeri bilimsel yöntemle sağlama alınabilecek bir şey değildir. O nedenle, bilimin değersizleşmesinde bilimin kendi payı olabilir; çünkü, bilim kurumunu olanaklı kılan ve ona olan güveni sağlama alan toplumsal ve değersel koşulları-yani kendisini-unutan bir bilimsel söylem, ancak yalnızca teknolojik ve araçsal bir etkinliğe denk olacak ve böylece toplumsal bağlamından kopacaktır. Öyleyse, nesnellik öznellikten tümüyle bağımsız bir şeymiş gibi düşünerek hakikat-ötesi kavramını kullanmanın bizleri getireceği yer, anlamlı herhangi bir tartışmanın imkânsız olacağı şu garip durumdur: Zevkler ve renkler tartışılmaz, çünkü onlar özneldir; bilimsel bilgi tartışılmaz, çünkü o nesneldir; geriye bir şey kalıp kalmadığı meçhuldür ve öyleyse yapılabilecek tek şey, bir gurup insanı aptal, cahil veya kötü niyetli ilan etmektir. ${ }^{2} \mathrm{Bu}$ sonuncunun akılsal değeri ise, sonucunu varsayan fasit dairelerin-yani yalnızca kendi kabilemize konuşabiliyor olma durumunun-değersizliğinin ötesinde değildir. Kavramın felsefi bir eleștirisi, nesnelliğin belirli tür bir tartışmadan bağımsız olamayacağını vurgulayarak, şu sonuca varmayı olanaklı kılar: Hakikat-ötesi diyerek kavramsallaştırılmaya çalışılan toplumsal durumun tehlikesi, her şeyin tartışılır hale geldiği kuralsız bir görecilik değil, herhangi anlamlı bir tartışmayı imkânsız hale getiren toplumsal bir bölünmüşlük ve çatışma

\footnotetext{
${ }^{2} \mathrm{Bu}$ durum hem belirli tür bilimsel araştırmalarda hem de siyasi söylemde ortaya çıkabilmektedir. Mesela, komplo teorilerine dair getirilen bir açıklamanın (van Prooijen vd. 2017) başlangış noktası, beynin olayları açıklamak ve çevreyle ilişki kurmak için olaylar ve varlıklar arasında düzenli ilisskileriörüntüleri-algılayan ve bu örüntülerin belirttiği düzen temelinde öngörülerde bulunan bir organ oluşudur. Fakat beynin bu özelliğinin yarattığı ve "yanılgısal örüntü algısı" olarak adlandırılan bir durum; bir tehlike hissedildiğinde ama tanıdık bir örüntü algılanmadığında, beynin kendisinin bir örüntü kurarak deneyime (gerçekte olmayan) bir düzen vermesidir. Yapılan araştırmaya göre, gözlemlenen bir durumda örüntüler bulma takıntısı ve akıldışı inançlar arasında bir korelasyon vardır. Yani yazı/tura gibi olasılıksal bir oyunda veya soyut bir resimde örüntü bulanlar, komplo teorilerine inanmaya daha yatkındır. Herkesin beyninin yapabildiği bu "etkinlik" — yanılgısal örüntü algısı — neden sadece bazı insanlarda ve şimdi bu kadar yaygınlaşabilmiştir? Dahası, gerçekten var olan örüntüyü, varmış gibi sanılan örüntüden ayırmak, fasit bir daireye girmeden, nasıl olanaklı olabilir? Eğer söz konusu olan yeti, olaylar ve varlıklar arasında ilişkiler kurmak ve bu ilişkilerin düzenini keşfetmekse, bilimsel bir araştırmanın yaptığı da nihayetinde bu değil midir? Ve en nihayetinde, olayların ve varlıkların düzenini keşfetme çabası, dünyanın bir düzeni olduğunu varsayarak başlayabilir. Yukarıda belirttiğim negatif açıklamaların siyasi düzlemden bir misali, Hillary Clinton'un, 2016 seçimlerinden önce Donald Trump'un destekçilerini bir takım "deplorables" olarak nitelendirdiği andır.
} 
halidir. Öyleyse kavramın felsefi bir eleştirisinin göstereceği ilginç sonuç, hakikatötesinde söz konusu edilmek istenen meselenin—en genel anlamıyla—siyasi oluşudur.

\section{Öznellik, Nesnellik ve Bilimin Değeri}

"Hakikat-ötesi" kelimesinin ilk kullanımı doksanlı yıllara dayanmakla birlikte, güncel tartışmalarda bir kavram olarak kullanımı 2016 yılındaki Amerika Birleşik Devletleri başkanlık seçimi ve İngiltere'deki "Brexit" referandumuyla yoğunlaştı. ${ }^{3}$ Yine aynı yıl, kelimenin Oxford İngilizce Sözlük tarafından yılın kelimesi seçilmesiyle, olabilecek en düz şekilde lügatimize girmiş oldu. Burada verilen tanıma göre, "hakikatötesi” şu demektir: "Kamuoyunun şekillenmesinde, nesnel olguların duygu veya kişisel inançtan daha az etkili olduğu durumlar." Sözlük anlamlarının felsefi tanımlar olmadığı aşikâr; fakat bir öz arayışından bağımsız olarak bile, burada söz konusu olan tanımın düz anlamının, eğer yeni bir durumu tanımlamaya çalıştığını varsayarsak, birçok karşıörneğe açık olduğu bir o kadar nettir: Hem gündelik yaşamda hem belirli uzmanlaşma prosedürlerinin kurduğu teknik bağlamlarda, kişisel inanç ve duygunun yargıların belirlenmesinde daha etkili olabiliyor oluşu ne yeni ne de garip bir durumdur. Kaza yapan bir sürücünün hatalı olanın karşı taraf olduğuna inanmaya yönelimi; kaza mahallini incelemeye gelen polisin, sürücünün arabasının markasına veya mesleğine göre kazayı raporlamaya olan yönelimi ve çıkılan mahkemenin hakiminin kanaatini oluştururken avukatın kimliğinden etkilenişi. Betimsel bir düzlemde ele alındığında, bu tür misaller hiç kimseye şaşırtıcı gelmeyecektir, çünkü özel veya kamusal yargıların şekillenmesinde kişisel kanı ve duygu gibi öğelerin kuvvetli etkisi tarihin en eski dönemlerinden beri farklı şekillerde söz konusu edilmiştir.

Fakat eğer verili tanımın örtük bir şekilde normatif bir değerlendirme içerdiği düşünülecek olursa, tanımın varsayımlarını açmak hakikat-ötesi kavramını çözümlemenin ilk adımı olabilir. Tanımın iddiası, kamuoyunun oluşmasında öznelliğin nesnellikten daha çok etkili olduğu durumların olduğu ve katıksız nesnelliğin tarafında konumlandırılan olguların etkisiz kalmasıdır. Tanıma normatif boyut kazandıracak olan

\footnotetext{
${ }^{3}$ Kavramın farklı alanlarda kullanımın detaylı bir tarihçesi için bkz. Gudonis 2017.
} 
varsayım kabaca şu şekilde ifade edilebilir: Bilişsel-yani doğru veya yanlış olabilecek-iddialarımız nesnel olmalıdır; nesnellik öznellikten arınmayı gerektirir, öznellik dediğimiz şey kişisel çıkar, ilgi, inanç, önyargı, vb.dir. Öyleyse hakikatötesinde söz konusu olan şey, kişisel çıkar, ilgi, inanç, önyargı vb.nin kamuoyunun şekillenmesinde nesnel olgulardan daha etkili hale gelmesidir. Herhangi bir kavramın esasen yapmaya çalıştığı şeyin, farklı olgu veya olayların tümüne ortak birtakım özellikleri belirlemek olduğu hatırlandığında; "hakikat-ötesi" kavramının bunu şu şekilde yapmaya çalıştığ 1 düşünülebilir. Aşı karşıtlığı, iklim değişikliğinin inkârı, evrim kuramının değersizleştirilmesi, siyasetçilerin yalanları, sosyal medyada dezenformasyon kampanyaları veya sahte haberler ve hepsinin kesiştiği yerde bir şekilde karşılaştığımız komplo teorileri-tüm bu ve benzeri durumlarda esasen olanın şu olduğunu düşünmemiz beklenmektedir: Bir tarafta nesnel gerçeklik—olgular-vardır; diğer tarafta ise öznel öğeler-kişisel kanı, inanç, çıkar, vb.- -vardır; ve şimdiki zamanı şekillendiren önemli bir özellik, kamuoyunun oluşumunda ikincinin birinciden daha etkili oluşu ve bu durumun kötü veya yanlış oluşu.

"Hakikat-ötesi” kelimesi, İngilizce "post-truth" kelimesinin yaygın kabul gören çevirisidir. İngilizce kelimedeki "post” öneki çift anlamlılığa sahiptir: (1) Bir durum veya karşıtlığın ötesine geçildiğini ve öyleyse artık o durum veya karşıtlığın değersiz, önemsiz, anlamsız veya geçersiz olduğunu ima edebildiği gibi; (2) zamansal veya tarihsel bir anlama da gelebilmektedir-yani zamansal bir siralamada bir durum veya olaydan sonra olan başka bir durum veya olayı ifade etmektedir. Öyleyse söz konusu kelimeyi "hakikat-ötesi” veya "hakikat-sonrası" olarak çevirmek mümkündür. "Hakikat-ötesi” çevirisinin yaygınlaşmış olmasının temel nedeni, burada söz konusu olanın zamansal ve tarihsel bir iddia olmadığıdır. Bu görüşe göre hakikat-ötesi kavramının meselesi, “önce hakikat vardı, sonra yok oldu” meselesi değildir. Kavramı o şekilde anlamaktan kaçınma çabasını motive eden nedenleri görmek zor değildir. Nihayetinde, Antik Yunan'da sofistlere kadar izini sürebileceğimiz bir gelenek vardır ve Platon'un Sokrates'in etkinliğini sofistlerden ayırmak için başvurduğu en net ifadelerden birisi, sofistin zayıf olan argümanı kuvvetliymiş gibi gösteren ve hakikatle 
ilgilenmeyen, Sokrates'in ise hakikati söze getiren kişi olduğudur (Platon, Savunma: 17b, 18c). Öyleyse hakikat-ötesinde söz konusu olan temel mesele, hakikatin tarihsel dönemlerde varlığı veya yokluğu değil, hakikatin önemsizleşmesi veya değersizleşmesidir. Eğer herhangi bir kavram anlaşılır olacaksa, belirli birtakım karşıtlıkları veya kontrastları varsaymalıdır: Mesela, doğru/yanlış, olgu/kurgu, iyi/kötü. Öyleyse hakikatin ötesinde olma durumu, bu karşıtlıkların geçerliliğini veya işlevselliğini kaybetmesine işaret etmektedir.

Fakat tam da burada-yani kavramın betimsel anlamının normatif anlamına dönüştüğü noktada — kaçınılmaz bir belirsizlik ortaya çıkmaktadır: Hakikatin değerine veya önemine dair bir iddia içerdiği vurgulanan bu kavram, bir şekilde aynı zamanda tarihsel bir dönemi işaret edercesine kullanılmaktadır. Hatta bu kullanım kazara olan bir şey değil, sanki zorunlu olarak böyledir. Çünkü eğer yalanın, sahtekarlığın, komplo teorilerinin, vb.nin sadece şimdiki zamana özgü şeyler olmadığını teslim edersek, bu kavrama neden şimdi ve bizler için ihtiyaç duyulduğu cevapsız kalmaktadır. Eğer hakikatin ötesinde olma durumu hakikatin—ve onun varsaydığg karşıtlıkların— değersizleşmesini içeriyorsa, kavramı o şekilde tanımlamak, ancak hakikate değer veren birilerinin-yani bu argümansal bağlamın varsaydığ 1 "bizler" —yapabileceği bir şeydir. Ve eğer hakikatin ötesindeyken hakikate değer vermek hala olanaklı bir şey ise, hakikatin ötesinde olanlar ancak ve sadece "onlar" olabilir. Fakat "onların" tarihsel olarak hep var olduğu teslim edildiği anda, şimdiki zamanı-yani bizleri ve onları kapsayan ve diğer dönemlerden ayıran bir özelliği-hakikat-ötesi diye bir kavramı ileri sürerek belirleme çabası esasen belirsiz kalacaktır. Başka bir şekilde ifade edecek olursak: Kavramın betimsel anlamı, normatif bir anlamı içermekte; normatif anlamı ise tarihsel—öyleyse betimsel—bir anlamı gerektirmektedir. Öyleyse burada söz konusu olan anlam belirsizliği, bir dikkatsizlik sonucu oluşan ve daha fazla kavramsal çözümlemenin aşabileceği bir sorun değildir ve kavramın kendisine dair eleştirel bir sorgulamanın gerekliliğini göstermektedir. ${ }^{4}$ Aksi durumda, hakikat-ötesi kavramının

${ }^{4} \mathrm{Bu}$ belirsizliğin görünür kılınması, yaygın tartışmalarda sıklıkla görülen bir "salınımı" anlaşıılır kılacaktır. Hakikat-ötesi bazen yalnızca bir tavır meselesine indirgenmekte-mesela Frankfurt'un belirttiği ve hakikat-ötesi kavramının bir öncüsü olarak nitelendirilen "hakikati umursamama" tavrı, 
taşıdığı bir risk, piyasa kurallarından ve disipliner paradigmalardan bağımsız olmayan akademinin işleyişinde, başka bağlamlarda "moda" olarak nitelenen sürecin analoğu olarak kalmaktır. Daha kötüsü, sanki artık hakikatin hakikaten değersiz olduğu yeni bir dönemdeymişiz gibi bir algı oluşturarak, tanımlamaya çalıştığı toplumsal durumu meşrulaştırma amacına devşirilmeye açık kalacaktır.

Öyleyse, hakikatin ötesinde olma durumunun ne ve nasıl olabildiğini anlaşılır kılmak için gerekli olan bir öğe, hakikatin kendisini sorunlu kılan bir şeylerin olduğunu teslim etmektir. Burada söz konusu olan etmenler birden fazla olsa da; bu çalışmanın sınırları içinde, önce bilişsel iddiaların gerekçelendirilmesi gerekliliğine dair olan bir yapıya başvuracağım. ${ }^{5}$ Daha sonra bu yapının barındırdığı zorluğun, hakikatin ne olduğuna dair yaygın olarak kabul edilegelmiş bir kuramı nasıl motive ettiğini ama aynı zamanda bu kuramın kendisi için birtakım sorunları içerdiğini göstereceğim. Bir bilgi iddiasının geçerliliğine dair neden sorusu sorulacak olursa-yani onu gerekçelendirmemiz istenecek olursa-bu ilk iddianın gerekçesi başka bir iddia olacaktır. ${ }^{6}$ Durumu böyle tasvir etmek, gerekçe arayışının nasıl ilerleyip, nerede

Frankfurt 2005-bazen de metafiziksel bir yapı veya tarih-ötesi bir dünya-görüşü statüsü kazanmaktadır (mesela Fuller 2018, özellikle ikinci ve üçüncü bölümler).

5 Söz konusu yapının Aristoteles'e kadar giden ifadeleri mevcuttur, mesela bkz. Metafizik $1011 \mathrm{~b} 25$ ve Kategoriler 12b11, 14b14. Gerekli soyutlamalar yapılacak olursak, benzer bir "motivasyonu" bazen Agrippa üçlemesi olarak adlandırılan yapıda da görmek mümkündür. Mesela, bkz. Franks 2005, özellikle Bölüm 1.

${ }^{6}$ Bilginin ne olduğuna dair yaygın olarak kabul edilen bir tanıma göre; bilgi, gerekçesi olan doğru inançtır. Bu tanımın içerdiği öğeleri, bilginin şartları olarak düşünmek mümkündür. Bu şartların her birine dair felsefi tartışmalar devam etmektedir. Yani neyin inanç, gerekçe ve doğru sayılacağının güncel tartışmalardan muaf bir tanımı yoktur. Fakat bu makalenin sınırları içinde belirtilmesinde fayda olacak iki husus var: 1) En genel anlamılla bir inancın veya iddianın gerekçesi, ona dair bir neden sorusuna verilmiş veya verilebilecek olan cevaptır. Bilgi için gerekçe gerektiği ısrarını motive eden düşünce, aksi durumda bilgi iddiasında bulunan kişinin inancıyla o kişinin bilişsel yetileri arasında uygun bir ilişki kurulmasının zor olduğu ve bu tür bir ilişkinin, iddianın bir bilgi iddiası olması için gerekli olduğudur; çünkü, mesela, doğru inanç rastgele veya şanslı bir tahmin de olabilir. 2) İlk bakışta, gerekçelendirme ve doğruluk şartları, birbirleriyle ilişkili olsalar bile, temel bir farkı barındırmaktadır. Gerekçesi olmasına rağmen yanlış olan bir inanç olabileceği gibi; doğru ama gerekçesiz bir inanç da olabilir. Yani geleneksel olarak inancın gerekçelendirilmesi meselesi, inanç sahibine (özneye) dair bir değerlendirmeyi içerir ve doğruluk şartı ile inanç şartı arasında uygun bir ilişkinin gerekliliğinden kaynaklanır: Bildiğimi iddia ettiğim şeye dair yeterli bir nedenim olması beklenmektedir. Yine geleneksel olarak doğruluk meselesi ise, inanç veya iddiaların gerçekliğe uygun, denk veya sadık olmaları ile ilgilidir. Bu anlamda doğru bir inanç veya iddia, gerçeğin ne veya nasıl olduğunu uygun/sadık şekilde temsil eden veya yansıtan bir inanç veya iddiadır. Metinde az sonra kuracağım argümanın bir amacı, burada söz konusu olan farkı mutlak ve keskin çizgilerle muhafaza etmenin bazı zorluklarını görünür kılmaktır. 
durabileceğine dair izlenebilecek üç yolu belirler. Birinci yol şudur: İlk iddianın gerekçesini verecek olan ikinci iddia, ilk iddiaya bağlıdır ya da onu varsayar. Mesela, “alkol tüketmek yanlıştır, çünkü alkol tüketmek günahtır”. "Günah” kelimesi dini bir bağlamı işaret ediyor olsa da içerdiği anlamın bir çeşit yanlış olduğu hatırlandığında, söz konusu yolun vardığı yerin fasit bir daire olduğu görülebilir. Yani bu durumda ilk iddia gerekçesiz kalacaktır. İkinci yol şudur: İlk iddianın gerekçesi olarak ileri sürülen ikinci iddia, kendi gerekçesi için üçüncü bir başka iddiaya başvurmayı gerektirir; o bir başkasına, o da bir başkasına... Mesela, “alkol tüketmek yanlıştır, çünkü karaciğere zarar verir, çünkü karaciğerin hücrelerini öldürür, çünkü doktorlar böyle söylemektedir, çünkü tıp fakültesinde böyle öğretilir...” Öyleyse bu yolun vardığı yer, nedenlerin sonsuza kadar uzanışıdır ve ilk iddia yine gerekçesiz kalır. Üçüncü yol ise, ilk iddianın gerekçesi olarak öne sürülen ikinci iddianın yalın bir iddia olarak kalmasıdır. Eğer bu yalın iddia dogmatik —yani nedensiz veya gerekçesiz-bir ileri sürüş olarak kalırsa, ilk iddia yine gerekçesiz kalmış olur. Öyleyse, ilk iddiayı destekleyecek bir gerekçe olacaksa, bu ikinci iddia bir şekilde bariz olmalıdır; yani gerekçeye ihtiyaç olmadan kabul edilebilmeli ve böylece neden arayışını tatmin edici şekilde durdurabilmelidir.

Bu bariz olma durumunu farklı şekillerde düşünmek mümkündür: Bir tanesi, onun kendi kendisinin gerekçesi olan bir iddia olduğudur; bir diğeri, onun başka öğelere çözümlenemeyecek şekilde basit olduğudur. Burada söylemek istediklerim için şu kadarını belirtmek yeterli olacaktır: Önümde bir kalem olduğunu iddia ettiğimde veya buna inandığımda, bu iddiayı veya inancı destekleyecek veya gerekçelendirecek nedenlere başvurabilirim — ve hatta, eğer söz konusu iddiamı veya inancı değilleyen başka iddialar veya inançlar varsa, ancak nedenlere başvurarak onun akılsallığını sağlama alabilirim. Ama nedenlerim bir yerde bitmek zorundadır ve bittikleri yer ancak şöyle bir durum olabilir: Önümde bir kalem olduğuna inanıyorum, çünkü önümde bir kalem görüyorum. Yani inançlarımız için neden arayışını tatmin edici şekilde sonlandırmanın bu yolu, akıl yürütmeyi gerektirmeden-yani kendisi bir neden gerektirmeden-dolayımsız olarak kabul edebileceğimiz bir "neden” olmalıdır. Bu 
“neden” öyle bir iddia olmalıdır ki, onda söz konusu olan şey bir şekilde gerçekliğin kendisidir.

Bilişsel iddialarımızı nedenler aracılı̆̆ıyla gerekçelendirme çabasının, nihayetinde gerçekliğin kendisini bizlere doğrudan verdiği bir öğede son bulması gerektiği görüşü, çok makul bir sezgiyi barındırır. Böylece hem gündelik yaşamda hem felsefi düşünce tarihinde etkili olan bir hakikat kuramını motive etmiş olur. Bu kurama göre, bir inancı veya iddiayı doğru yapan şey, ona karşılık gelen bir olgunun olmasıdır. Sorun şudur ki, bu oldukça makul düşünceyi tutarlı ve yeterli şekilde tanımlama çabaları genel bir uzlaşıya varmış değildir. Bir inancın veya önermenin bir olguya karşılık veya denk gelmesinin ne demek olabileceğinin bariz bir şey olmamasının yanında; bu karşılık veya denkliği nasıl bilebileceğimiz de sorunlu bir meseledir. Çünkü söz konusu denkliğin kendisi ancak başka inanç veya önermeler-başka iddialararacılığıyla söze gelebilir. Bu meselenin düz bir çözümü olduğu varsayımına destek sunan şöyle bir hayal vardır: Bir tarafta bizler-yani inançlar, iddialar, kavramlar veya kuramlar_varız; diğer tarafta ise olgular_yani gerçekliğin kendisi—var ve hakikat, bu taraf o tarafa denk geldiğinde olan şeydir.

Bu tasviri bir hayal olarak nitelendirmemin temel nedeni, onun yanlışlığının bir ispatı oluşu değildir; "hayal” ile işaret etmek istediğim durum, hakikati inancın olguya denkliği olarak tanımlamanın farazi varsayımları olduğu ve o tanımın terimleri içinde bu varsayımları gerekçelendirmenin zorluğudur. $\mathrm{Bu}$ zorluğun en temel nedeni ise, tanımın bir kutbunu oluşturan gerçekliğin kendisinin, kendi adına konuşabilen bir şey olmayışıdır. ${ }^{7}$ Yani ona dair iddialarımızı destekleyebilmek için başvuracağımız öğeler, başka iddialar olmak zorundadır. Bu zorunlukta 1srar etmek, gerçeklik yoktur demek değildir. Söz konusu zorunluğun çıkarımı, hakikatin ne olduğunu, düz bir şekilde ve

\footnotetext{
${ }^{7} \mathrm{Bu}$ zorluğun çözümünü, inanç veya önermelerin bir şekilde gerçekliğe çıpalandığı başka "önermelerde" —mesela "gözlem cümleleri" veya "protocol cümleleri" — bulma çabasını en tutarlı ve ısrarlı şekilde barındıran "mantıksal pozitivizm/deneycilik" in tecrübesi, bu hususta öğreticidir. Kuramsal kavramları içeren önermeleri, içinde yalnızca duyusal öğeleri barındıracak "önermelere" indirgeme çabası, yine kuramsal öğelerin-yani "duyu-verileri”nin—ileri sürülmesini gerektirdiği gibi; çabanın kendisini düzenleyen kanıtlanabilirlik ilkesinin, kendi sınavını geçtiği bir ifadesine varmak mümkün olmamıştır. Mesela, bkz. Ayer 1936 ve Berlin 1938.
} 
doğrudan gerçekliğin kendisine çıpalamanın (veya temellendirmenin), gündelik sezgilerimizin aksine, bariz bir düşünce olmayışıdır. Bu zorluğu ortaya çıkaran varsayımların sorgulanması, hakikati gerçekliğin kendisi üzerinden anlamaktansa, onu iddialarımızı gerekçelendirme pratiklerimiz üzerinden anlamaya yönlendirir. ${ }^{8}$

${ }^{8}$ Bu yönelimin kendisi zorluklar içermektedir. Fakat bu makalenin sınırları içinde göstermek istediğim şey yalnızca, onu motive eden nedenlerdir. Eğer bilişsel iddialarımıza dair nedensel bir talebin başlattığ gerekçelendirme süreci ya keyfi olan bir noktada son bulacak ya sonsuza uzanacak ya da olduğu yerde dönüp duracaksa; bu durum çevremizle ve kendimizle kuracağımız bilişsel ilişkinin tatmin olamayacağı anlamına gelir. Geleneksel veya klasik olarak felsefede etkili olan bir düşünce, bu üç sonuçtan kaçınan bir yol olduğu ve gerekçelendirme taleplerimizi tatmin edecek imtiyazlı bir durma noktasına varabileceğimizdir. Bu "durma noktası" öznel tasarımlarda veya nesnel doğada (“duyunun verdikleri”) konumlandırılabilir. Gerekçe arayışımızı durduracak böyle bir nihai nokta olması gerektiği düşüncesi, doğruluğu inanç veya iddialarımızın gerçekliğe denkliği veya sadakati olarak belirleyen hakikat kuramının temel motivasyonu olarak düşünülebilir. Fakat eğer özne ve nesneyi birbirlerinden tümden bağımsız iki kutup olarak alırsak ve bilişsel yargı üretimi meselesini, bu iki kutuptan birinin diğerini bir ayna gibi yansıttığı bir temsil ilişkisi olarak kurgularsak ve eğer doğruluğu nihayetinde bu tür bir temsil ilişkisinin gerçekliğe sadakati olarak nitelendirirsek, bu ilişkiyi gerekçelendirecek ve sonucunu varsaymayacak - bir şekilde döngüsel olmayan - bir argüman olamayacaktır. Çünkü bu temsiliyet durumu ya nesnenin özneye kendisini olduğu gibi vermesi olabilir - ki bu durum açıklanması gereken ilişkiyi, yani nesnenin özneyle nasıl doğru şekilde "temasa" geçtiğini varsayacaktır-ya da bu temsiliyet sadece öznenin etkinliğinin sonucu olarak kurgulanabilir-ki bu durum öznenin kendi dışına çıkıp gerçekliği "okuyabilme" yetisini, yani açıklanması gereken ilişkiyi, yine varsayıyor olarak kalacaktır. Bu ikilemin etrafından dolanmaya çalışıp hem özneden hem nesneden bağımsız olacak ve ikisinin arasındaki bağın sadakatini veya denkliğini sağlama alacak üçüncü bir öğeye başvuracak olursak; bu sefer de bu üçüncüyü nasıl doğru, yani sadık şekilde, temsil edebileceğimiz sorusuyla karşı karşıya kalırız. Bu da ikilemin sadece terimlerini değiştirip yapısını korumakla eşdeğerde olacaktır. Eğer bu zorluk teslim edilirse, yani özne ve nesne arasındaki ilişkiyi doğru şekilde betimlememize imkân verecek ama özneye (inanç, iddia, vb.) hiçbir şekilde bağlı olmayacak mutlak olarak nesnel bir öğeye dair iddialarımızın veya inançlarımızın kendileri, onları neden doğru olarak kabul edebildiğimiz sorusunu kaçınılmaz olarak sormayı gerektirirse; bilgi ve doğruluk sorunsalını gerçekliğin sadık temsili amacından farklı bir düzlemde yeniden kurma isteğini motive eden neden anlaşılabilir. Doğruluğu, sadık temsiliyet yerine gerekçelendirmenin bir fonksiyonu olarak tanımlayan bu hareketin başlangıç noktasını Kant'ın Salt Aklın Eleştirisi'nde konumlandırmak mümkündür. Burada Kant'ın stratejisini belirleyen ana fark "olgu sorusu" ve "hak sorusu" olarak tanımlanır ve Kant bu terimleri hukuki anlamlarında kullanacağını belirtir (Kant 1998: A84/B116; A669/B697). Yani arttk as1l epistemolojik soru, temel kategorilerimizi kullanma hakkımızın meşrulaştırılmasıdır. $\mathrm{Bu}$ da kategorilerimizin nesnel geçerliliği sorunsalının bir gerekçelendirme sorunu olduğuyla eşdeğerdir. Ayrıca Kant, bu yeni yönelimi, doğruluğu gerçekliğe denklik veya sadakat olarak tanımlayan geleneksel doğruluk kuramının sorunlarıyla ilişkilendirir (bkz. Bxvi-Bvii). Sorunun burada bulduğu ifadenin terimlerine göre; eğer doğruluk kavramlarımızın onlardan tümüyle bağımsız nesnelere bir şekilde denkliği veya uyumu olarak tanımlanacak olursa, bu şüpheciliği olanaklı kılacaktır. Çünkü tasarımlarımızın dışına çıkıp, onların gerçekliğe denk veya uygun olup olmadıklarını belirlememiz imkansızdır. Öyleyse o tür bir doğruluk tanımı gündelik bağlamlarda kabul edilebilir olsa da doğruluğun genel bir tanımı olarak yetersizdir. Kant'ın devrimsel bir dönüşüm olarak sunduğu teklif, doğruluğu nesnelerin kavramlarımıza denkliği veya uyumu olarak anlamaktır. Teklifin bir çıkarımı; doğruluğu, deneyimlerimizin (deneyimin biçimini veya yapısını kuran) evrensel ve zorunlu kategorilerle olan uyumu üzerinden anlamamız gerektiğidir. Bu makalenin argümanı için, bu çıkarımda önemli olan öğe, öznelliğin deneyim ve bilgi söz konusu olduğunda yalnızca edilgin olmadığı, asgari olarak kurucu ve etkin bir rolü olduğudur. 
Hakikati, gerçekliğin kendisinin—olguların—herhangi öznel bir etkinliği devre dış1 bırakacak şekilde verili olduğu bir durum olarak düşünmek, bilimsel bilgi söz konusu olduğunda daha karmaşık zorlukları içerir. Çünkü ilginç bilimsel iddia ve açıklamalarda söz konusu olan şey-önümde bir kalem olduğu inancında görece sorunsuzca devre dışı bıraktığımı hayal ettiğim-kuramsal ve deneysel bir etkinliğin yadsınamayacak varlığıdır. Kalemler ve masalardan farklı olarak; elektronlar veya manik-depresif kişilikler, bakıp gördüğümüz olgular değil, açık şekilde kuramsal öğelerdir. Öyleyse yapılması gereken şey, belirli tikel alanlarda doğru veya yanlış_ bilişsel — iddialar ileri sürmemizi ve böylece "gerçekliği”" belirli şekillerde "kurmamızı" olanaklı kılan koşulları hesaba katan bir nesnellik kavramına başvurmaktır. Burada söz konusu olan "gerçekliğin kurulması" fikri, birçok yanlış anlamaya ve yanlış kullanıma açıktır. $\mathrm{Bu}$ çalışmanın sınırları içinde vurgulayacağım iki husus olacak. Birincisi, önermelerin kabul-edilebilirlik koşulları ile ilgilidir. Foucault'nun sunduğu bir misal aydınlatıcıdır. İddialarının doğruluğunun kendi zamanının ilgili araştırmacıları tarafından tanınmadı̆̆ Mendel'in iddialarının, yanlış olarak bile değerlendirilebilmelerine öncel bir koşul vardır; yani bir önermenin yanlış olarak değerlendirilmesi için, önce "hakikate-dair" olarak tanınması gerekmektedir. Fakat "Mendel hakikati söyledi... hakikatin içinde değildi" (Foucault 1972: 224). Burada söz konusu olan, tikel bir alanda nelerin doğruluğa veya yanlışlığa dair bir değerlendirmenin adayı olarak tanınabileceğini, nelerin olgu olarak tanımlanabileceğini, hangi tür ölçümlerin veya hangi tür iddiaların meşru adaylar olarak kabul edilebildiğini ve en genel anlamıyla nelerin neden olarak sayılabileceğini belirleyen bir art alandır. ${ }^{9}$

Hakikati gerçekliğin kendisinin özneye doğrudan verilişi olarak düşünmenin içerdiği zorluklar, başka hakikat kuramlarının vesilesi olmuştur. Bunlardan bir tanesine göre, bir inanç veya iddiayı doğru yapan şey, onun tutarlı bir iddia sisteminin parçası

9 Önemli farklar içerse de burada Foucault'nun "tarihsel a priori” kavramı ile bu hususta ilişkilendirebileceğimiz başka kavramlar da mevcuttur. Mesela, Kuhn'nun belirli bir araştırma alanında yasaları, kuramları, uygulamaları ve araçları içeren ve "normal bilimi”" olanaklı kılan "paradigması", Kuhn 1996: 10. (Paradigmanın tikel kavram, yasa ve kuramlara öncelliği için, bkz. Kuhn 1996: 11); olguların kuvvetini esasen belirleyen şeyin hakikat değil, onları "üreten" ve onlara ifade veren kurumlar ve pratikler olduğu iddiasını içeren, "olguların ağlaştırılmış [networked]" olduğu düşüncesi Latour 2005; ve dünyanın "olgulaştırılışının” bir insan etkinliği olduğunu vurgulayan Hacking 2002: 65. 
olmasıdır. Yani burada hakikat, inancın olguya uyması değil, başka inançlarla bir sistem oluşturabilecek şekilde uyuşması veya bağdaşmasıdır. Şüphe durumunu yaşadığımızda veya bir iddiayı gerekçelendirme ihtiyacı ortaya çıktığında yaptığımız şey, inançlarımızı veya iddialarımızı tek tek gerçekliğin kendisiyle karşılaştırmak değildir. Yani bilgiyi gerekçelendirme pratiklerimiz hiçbir zaman sıfırdan başlamaz. Bu durumu iyi ifade eden bir imge Neurath'1n gemisidir (Neurath 1973: 199). Bu imgenin sunduğu karşılaştırmaya göre, inançlarımızı sınamak ve yeniden değerlendirmek, bir gemiyi açık denizde onarmak gibidir. Geminin bir parçasını onarmak için kullanabileceğimiz yegâne şeyin ancak geminin bir diğer parçası olabileceği ve bu onarımı yaparken üzerinde durup destek alacağımız yerin, ancak geminin başka bir yeri olabileceği gibi; inançlarımızı sınamak ve yeniden değerlendirmek için başvurabileceğimiz öğeler ancak inanç sitemimizin içerdiği diğer inançlar olabilir. Öyleyse, eğer bilgimizi temelden inşa etmek imkansızsa, yapabileceğimiz tek şey; birtakım inançları varsayarak diğer inançlarımızı değerlendirmektir. Bu değerlendirmenin varsaydığı inançları yeniden değerlendirmek olanaklıdır elbette; fakat bu yeniden değerlendirmenin destek bulacağı zemin gerçekliğin kendisi değil, inanç sistemimizin—bu ikinci değerlendirmede doğru varsayılan-diğer inançlarıdır.

Hakikatin ne olduğuna dair bu faklı kuramları, "hakikat-ötesi" kavramına dair tartışmalarda hatırlamak iki temel nedenden dolayı gerekli ve faydalıdır: 1) Aksi durumda, hakikatin kamusal değerinin yoğun baskı altında olduğu güncel durumumuzda, hakikati savunma arzusu bizleri daha önce denenmiş ve savunulması güç hakikat kuramlarında sığınmaya itebilmektedir ve 2) eğer hakikat sadece verili veya bulunan bir şey değil, toplumsal pratiklerimizin ördüğü koşulları gerektiren bir etkinlikse; bu pratiklerin varlığını ve etkinliğimizin sınırlarını teslim etmek, bizleri hakikati savunmak adına daha etkili stratejilere yönlendirebilecektir.

Mesela, hakikat-ötesi tartışmalarında, bilimsel bilginin değersizleştirilmesinin veya inkârının önemli bir örneği olarak sıklıkla başvurulan bir tartışma, evrim kuramı ve yaratıcılık arasında yaşanan ihtilaftır. İhtilafın bir tarafı olan evrim kuramına göre, canlı türlerin oluşumunu ve gelişimini açıklamak demek, doğal seçilim mekanizmasına 
başvurmak demektir. Doğal seçilimin barındırdığı temel düşünce ise, bir organizma türünün nüfusunda bulunan bireylerin arasında rastgele ortaya çıkmış olan değişimlerin sonucu olan farkların mevcut olduğu ve bu farklı özelliklerin içinden, üreme başarısına katkıda bulunanlarının seçilerek zaman içinde o türün dönüşümünü sağlayacağıdır. Evrimsel açıklamaları düşünce tarihinde yeni bir düşünme biçimi olarak belirleyen şey, söz konusu açıklamaların tümüyle materyalist oluşlarıdır. Yani burada söz konusu olan seçilim fikri, herhangi bir bilinci veya tasarımı varsaymamaktadır ve teleolojik açıklamalara gerek olmadan da canlı organizmaların dönüşümlerinin anlaşılabileceğini vurgulamaktadır. Öyleyse evrimsel açıklamaların içerdiği devrimsel düşünce; türlerin evrimi iddiası değil, bu evrimin amaçsız ve tasarımsız fiziksel bir süreç olarak anlaşılabileceğidir. Yaratıcılık ise, karmaşık organizmaların oluşumunu açıklamak için bilinçli bir tasarıma — ve nihayetinde ilahi bir iradeye — başvurmanın gerekliliğinde ısrar eden bir görüştür.

Bu ihtilafın güncel tartışmalarda karşılaştığımız sürümleri, evrim kuramının bir kuram mı yoksa bir olgu mu olduğuna dair garip bir soru olarak sunulmaktadır. İhtilafın taraflarından olan ve kendisinin de bilimsel bir kuram olarak kabul edilmesi gerektiğinde ısrar eden yaratıcılık; kendisinin de bilimsel bir kuram olarak kabul edilmesi adına, evrim kuramının bir olgu değil, bir kuram olarak nitelendirilmesinde 1srar etmektedir. Bilimsel nesnelliğin kurulan bir şey olduğunda 1srar etmek; sanki o tartışmada evrim kuramını değersizleştirmek için, onun olgu olmadığını söylemeye denkmiş gibi algılanabilir. Güncel tartışmanın varsayımlarına göre, evrim kuramına inanan bizlerin, "hayır, o bir olgu" demesi beklenmektedir. Fakat evrim kuramı gerçekten de bilimsel bir kuramdır ve bu tartışmada esasen söylememiz gereken şey, yaratıcılığın $o$ anlamda bir kuram bile olmadı̆̆ıdır. Burada evrim kuramını bir kuram olarak belirlemenin işlevi, onu geçersiz veya ("sadece kişisel tercihe bağlı" anlamında) öznel olarak nitelendirmek değildir; kuram belirlemesinin bu bağlamda kontrastı, en düz anlamıyla ne evrimin ne doğal seçilimin bakıp gördügümüz-yani duyuların doğrudan verdiğgi-öğeler olmadığıdır. Mesela, fosillerin varlığının evrimin veya doğal seçilimin ispatı olamayacağı gibi; Darwin için bile söz konusu mekanizma bir hipotezdir. Bu 
hipotezin kendisini gerekçelendirmek için başvurduğu nihai neden ise, belirli bir araştırma alanında, diğer mevcut kuramlardan daha açıklayıcı-daha az varsayımla, daha tutarlı olarak, vb.-olduğudur. Yirminci yüzyılda genetik biliminin gelişmesi ve böylece doğal seçilim mekanizmasının nasıl etkinleştiğine dair yeni gözlemlerin olanaklı kılınması, evrim kuramının alternatiflerine olan üstünlüğünü arttırmıştır.

Öyleyse söz konusu ihtilafa dair vurgulanması gereken önemli nokta, bir kuramın kavram ve ilkelerinin kısıtlarından bağımsız olarak bir olgunun söz konusu olamayacağıdır. Yani nelerin bir olgu olarak sayılacağını ve hangi (akılsal) biçimde birbirleriyle ilişkilendirileceğini belirleyen şey, bir kuramın içinde barındırdığı kısıtlar ve sınırlandırmalardır. Bir biyoloğun bakışının mikroskopta gördükleri ile gerekli kuramsal çerçeveye sahip olmayan bir bakışın gördükleri, bu anlamda, aynı şey değildir. Kuramın kendi bağlamında, ileri sürülen iddiaların hangilerinin doğru-veya-yanlış bir hipotez olarak kabul edilebileceğinin yargısına varabilecek kişiler, ilgili alanda araştırma yapan bilim insanlarının oluşturduğu topluluktur. Her ne kadar neyin bir kuram olarak kabul edilip edilmediği karmaşık bir süreci barındırıyor olsa da belirli bir alanda bir grup önermenin kuram sayılıp sayılamayacağının nihai otoritesi, ilgili bilim insanları topluluğunun uzlaşımıdır. Öyleyse yapılması gereken şey, "kuram” ifadesini göreli öznelliğin, "olgu” ifadesini ise mutlak nesnelliğin emaresi yaparak karşılaştırmak değil; hakikati bir uzlaşının sonucu olarak düşünebilmektir.

Yaratıcılığın bu anlamda bir kuram bile olmaması-yani dini bir inanc1 barındırması-onu tümüyle değersiz kılmaz. Çünkü (1) belki canlı türler gerçekten (ilahi bir varlık tarafından) tasarlanarak yaratılmış olabilir. Ama bunu bilimsel olarak gösterecek olan şey, bunu gösterebilen bilimsel bir kuramın ileri sürülmesidir ve (2) inancın dini olanının kendi bağlamının başka değerleri olabilir. Öyleyse yaratıcılığın yaptığ 1 şekilde, bilimin dilini konuşuyormuş gibi yaparak dini olanı bilimin yerine koymaya çalışmak; her şeyden önce dini inancın hakkını yemektir. Bu ikinci durum, söz konusu ihtilafın güncel tartışmalarının gözden kaçırdığı önemli bir noktaya işaret etmektedir. Evrimsel açıklamaların neyi ne kadar açıkladığını, argümanlar ileri sürerek sorgulamak mümkündür. Aynı zamanda, evrimsel açıklamaların kapsamına dair, ilgili 
her bilim insanı hemfikir değildir. Mesela, evrimsel açıklamaların yalnızca insan türüne has genel ve biyolojik özelliklerin açılanmasında kullanımının meşru olduğunu savunan argümanlar olduğu gibi; tüm insan davranışlarının, hislerinin ve düşüncelerinin-yani genelde toplumsal, kültürel veya zihinsel olarak nitelenen özelliklerin — de evrimsel açılamalarla tümüyle biyolojik süreçlere indirgenebileceğini savunan argümanlar da vardır. ${ }^{10}$

Fakat bu kapsama dair tartışmalardan bağımsız olarak, evrim kuramının belirli bir bağlamda tanımladığg olguları açıklamakta alternatiflerinden daha başarılı olduğuna dair bilimsel bir uzlaşı mevcuttur. Yaratıcılığın yaptığı ise, mesela on dokuzuncu yüzyılda Darwin karşıtı bazı iddiaların aksine, dini bir otoriteye başvurmak ve ilahi tasarım fikrini bu otorite temelinde gerekçelendirmek değildir. Tam tersine, yaratıcılık, bilimselliğin dilini kullanıyormuş gibi yaparak — yani kendisini bilimsel bilgi zemininde konumlandırma çabasıyla eşzamanlı olarak-bilimin otoritesini sorgulamaktadır. ${ }^{11}$ Yani kendisiyle çelişmektedir. Öyleyse "kuram mı, olgu mu?" şeklinde ifade bulan ihtilaf, hakikat-ötesi durumunun tehlikelerinden bir diğerine işaret etmektedir. Bilimsel bilginin olanaklılık koşullarına ve kuramların değerlendirilmesine dair meşru olabilecek bir sorgulama; güncel bir kamusal tartışmada "kuram mı, olgu mu?" şeklinde kurularak, bizleri yanlış bir ikilemin terimleri arasına sıkıştırmaktadır. Tartışma o şekilde kurulduğu anda ise, toplumsal gerçekliğimiz iki tavır arasında yapılacak bir seçime

10 İkinci görüşün klasik ifadesi için bkz. Dawkins 1976; evrim kuramının kapsamının nüanslı bir tartışması için bkz. Gould 1997. Evrimsel açıklamaların kapsamına dair tartışmaların bir spektrum oluşturdukları düşünülebilir. Kabaca söyleyecek olursak, spektrumun bir ucunu oluşturan görüş, insan doğasına dair klasik soruları, insanı tümüyle bir "gen makinesi" olarak yeniden tasvir ederek açıklamayı; diğer ucu oluşturan görüş ise, en genel anlamıyla kültür temelli açıklamaların otonomi sahibi olması gerektiğini savunmaktadır. Çoğu dikkatli yazar bu iki ucun arasında bir yerde konum almaktadır. O nedenle Dawkins'i sadece bir uçta konumlandırmak pek adil olmayabilir. (Kaygı dergisinin atadığı bir hakeme, bu hususa dikkatimi çektiği için teşekkür ediyorum.) Evrimsel açıklamaların insan davranışlarında geleneksel olarak kültürel veya toplumsal diye nitelendirebileceğimiz tavır ve davranışlara daha katıksız uygulanışının bir örneği için bkz. Trivers 1972.

${ }^{11} \mathrm{Bu}$ hususun, hakikat-ötesi tartışmalarının bilimin otoritesini ilgilendiren boyutunda gözden kaçan ama vurgulanması gereken bir durum olduğunu düşünüyorum. Mesela, İkinci Dünya Savaşı sırasında toplama kamplarının varlığını reddeden veya sistematik olmadıklarını ileri süren tarihçiler, iddialarını desteklemek için bilimsel yöntemden tümüyle bağımsız sunumlara başvuruyor değildirler; yine bilimin dilini konuşuyormuş gibi yaparak, kanıt, belge, argüman, vb. dilini kullanmaktadırlar. Soykırım inkarının ve toplama kamplarına dair "revizyonist" bir anlatı sunan David Irving’in "tarihçiliğinin" detaylı bir tartışması için bkz. Evans 2001. 
indirgenmiş olur: Evrim kuramının sadece bir kuram olduğunu ileri sürerek onu değersizleştirmeye çabalamak veya onun esasen bir olgu olduğunu ileri sürerek onu savunmaya çalışmak. Biri ve diğeri aynı durumun sonucudur ve bilimsel nesnelliğin nasıl kurulduğuna dair yanlış varsayımları taşımaktadır. Öyleyse burada söz konusu olan, bilişsel bir meseleymiş gibi sunulan bir tartışmada esas olanın, verili ve sabit olarak konumlandırılan iki kabile arasında bir seçime zorlanışımızdır. Oysa seçeneklerimiz bilimsel nesnellik veya dini inanç olmak zorunda değildir. Yani misal tartışmanın amacı, sorgulayıcı herhangi bir tartışmayı imkânsız kılmak ve dolayısıyla safları sıkılaştırmaktır.

\section{Sonuç}

Hakikat-ötesi kavramı kaçınılmaz şekilde bir çift anlamlılığı barındırmaktadır. Betimsel anlamı, normatif bir anlamı içermekte; normatif anlamı ise, tarihsel bir anlama yönlendirmektedir. Bu nedenle kavramayı çalıştığı muhtelif durumları anlaşılır kılma hususunda faydası oldukça sınırlıdır. Ayrıca, kavramın yaygın kabul gören anlamı, nesnellik ve öznelliği birbirlerinden tümüyle bağımsız düşünülebilecek kutuplar olarak konumlandırmakta ve böylece nesnelliğin kurulumunda varsaymamız gereken öznel bir etkinliği göz ardı etmektedir. Burada söz konusu olan öznellik, bir kişinin bireysel kanaat ve çıkarlarına bağlı olarak düşünülmek zorunda değildir. Söz konusu olan etkinlik, bilimsel bilginin olanaklılık koşullarını bulduğu ve değerini sağlama alabildiği toplumsal pratiklerin ördüğü bir art alandır. Bu art alanda söz konusu olan ise, ortak bir dili etkinleştiren pratikler ve kurumlardır. Hakikatin sorunlu ve ancak belirli tür bir tartışmanın sonuncunda varılabilecek bir şey olduğunu teslim etmek; hakikat-ötesinde esasen söz konusu olanın nesnelliğin zayıflaması değil, öznelliğin zayıflaması-yani yalnızca kişisel inanç ve çıkarlardan oluşan ve eleştirel etkinlikten yoksun olanolduğunu görünür kılacaktır. ${ }^{12}$ Catherine Legg'in Peirce'den esinlenerek ifade ettiği

\footnotetext{
${ }^{12}$ Hakikati ancak belirli tür bir tartışmanın sonucunda varılabilecek bir şey olarak düşünmenin kendisi de bazı zorluklar barındırmaktadır elbette. Bu makalenin sınırları dışında olsa da bu zorluğun bir işaretini vermek adına şu kadarı söylenebilir. Eğer gerekçelendirme etkinliğimizin normatif bir eylem olduğu, nedensel alış-verişlerimize yön veren normların kendilerinin ise ancak ve nihayetinde toplumsal eylemler ve yaptırımlar bağlamında anlaşılır kılınabileceği kabul edilirse; bunun bir çıkarımı sanki şudur: Doğruyu
} 
gibi, “kötü kanıların çözümü diğer kanılardır” (Legg 2018: 43). Öyleyse irdelenmesi gereken süreç, öznenin bu şekilde güçsüzleşmesinin oluşumudur.

ve yanlışı belirleyen nihai kriteri bir topluluğun kabulleri ve retlerinde konumlandırmak. Fakat Newton'un yasalarının doğruluğunu veya cinayetin kötülüğünü belirleyen nihai neden bir topluluğun bunları öyle veya böyle kabul ediyor oluşudur demek, sorumsuz veya gayriciddi bir görecilikle özdeştir gibi görünebilir. Öyleyse hakikati bağımsız gerçekliğe denklikten veya sadakatten farklı olarak bu şekilde yeniden düşünmemiz gerektiğini savunan görüşler, bu zorluğa bir cevap verebilmelidir. 


\section{KAYNAKÇA}

ARISTOTLE (1984). The Complete Works of Aristotle, Vol 1 and 2., ed. Jonathan Barnes, Princeton University Press.

BAŞKIR, Ünsal Doğan (2020). "Yalan, Hakikat, Siyaset: Arendtçi Bir Bakış", İzmir Felsefe Günleri 2019 Bildiri Kitabı (Dokuz Eylül Üniversitesi, Edebiyat Fakültesi, Felsefe Bölümü), Konak Belediyesi Yayınları.

BERLIN, Isaiah (1938). "Verification", Procedeedings of the Aristotlean Society, 39/1938: 225-48

COSENTINO, Gabriele (2020). Social Media and the Post-Truth World Order The Global Dynamics of Disinformation, Palgrave Macmillan.

D'ANCONA, Matthew (2017). Post Truth: The New War on Truth and How to Fight Back, Ebury Press (e-book).

DAWKINS, Richard (1976). The Selfish Gene, Oxford University Press.

EVANS, Richard John (2001). Lying About Hitler: History, Holocaust, and the David Irving Trial, Basic Books.

FRANKFURT, Harry Gordon (2005). On Bullshit, Princeton University Press.

FRANKS, Paul Walter (2005). All or Nothing: Systematicity, Transcendental Arguments and Skepticism in German Idealism, Harvard University Press.

FOUCAULT, Michel (1972). The Archaeology of Knowledge and the Discourse on Language, Pantheon Book. Press.

FULLER, Steve (2018). Post-Truth Knowledge as a Power Game, Anthem

GUDONIS, Marius (2017). "How Useful Is the Concept of Post-Truth in Analyzing Genocide Denial? Analysis of Online Comments on the Jedwabne Massacre", Zoon Politikon, 8/2017: 141-182.

HACKING, Ian (2002). Historical Ontology, Harvard University Press.

HARSIN, Jayson (2015). "Regimes of Post Truth, Post Politics, and Attention Economies", Communication, Culture \& Critique, 8(2)/2015: 327-333.

HARSIN, Jayson (2018). "Post-truth and Critical Communication", Oxford Research Encyclopedia of Communication,

(https://oxfordre.com/view/10.1093/acrefore/9780190228613.001.0001/acrefore9780190228613-e-757).

KAKUTANI, Michiko (2018). The Death of Truth, Tim Duggan Books. 

Macmillan.

KALPOKAS, Ignas (2018). A Political Theory of Post-truth, London: Palgrave

KANT, Immanuel (1998). Critique of Pure Reason, çev. Paul Guyer ve Allen W. Wood, Cambridge University Press.

KEYES, Ralph (2004). Post-Truth Era Dishonesty and Deception in Contemporary Life, St. Martin's Press.

KOFMAN, Alexander (2018). "Bruno Latour, the Post-Truth Philosopher, Mounts a Defense of Science. Interview with Bruno Latour", (https://www.nytimes.com/2018/10/25/magazine/bruno-latour-post-truth-philosopherscience.html).

KUHN, Thomas Samuel (1996). The Structure of Scientific Revolutions, The University of Chicago Press.

LATOUR, Bruno (2005). Reassembling the Social An Introduction to ActorNetwork Theory, Oxford University Press.

LEGG, Catherine (2018). "“The Solution to Poor Opinions Is More Opinions': Peircean Pragmatist Tactics for the Epistemic Long Game", ss. 43-58, Post-Truth, Fake News, Viral Modernity \& Higher Education, ed. Michael A. Peters, vd., Springer.

MCLINTYRE, Lee (2018). Post-truth, MIT Press

NEURATH, Otto (1973). “Anti-Spengler”, Empiricism and Sociology, ss. 158213, D. Reidel Publishing Company. Company.

PLATON (1997). Complete Works, ed. John Cooper, Hackett Publishing

TRIVERS, Robert Ludlow (1972). "Parental investment and sexual selection." Sexual Selection and The Descent of Man 1871-1971, ed. B. Campbell, Aldine Publishing Company.

VAN Prooijen vd. (2017). "Connecting the dots: Illusory pattern perception predicts belief in conspiracies and the supernatural", European Journal of Social Psychology,

(https://journals.plos.org/plosone/article?id=10.1371/journal.pone.0225098).

YAZICI, Çiğdem (2020). "Hakikat Sonrası Duygular ve Eleştirel Düşünce", Cogito: Eleştiri Zamanı, 100/2020: 246-254. 